\title{
Comparative Overview of the Presence of Intercultural Education of Teacher Trainees in Serbia and Bosnia and Herzegovina
}

\author{
Mila Beljanski ${ }^{1}$ \\ University of Novi Sad, Serbia \\ Emina Dedić Bukvić \\ University of Sarajevo, Bosnia and Herzegovina
}

\begin{abstract}
The focus of the present paper is on the importance and significance of interculturality in teacher education. The paper analyzes the intercultural content of the curricula to develop the intercultural competencies of future teachers in Serbia and Bosnia and Herzegovina. The sample analyzed was the curricula of the universities of these two countries for the academic year 20182019. The analysis of the chosen documents examined the areas of teaching, content, as well as other elements that represent possible opportunities for developing the intercultural competencies of the students. The analyzed curricula do not offer an insight into the results of the teaching practice, which is one of the limitations of this study. The findings on the poor ratio of intercultural elements in the curricula and the need for their revision, as well a necessity of introducing systematic intercultural education to teacher colleges and universities of education are a valuable contribution. Competent teachers will create a positive environment for proper intercultural communication and develop the intercultural sensitivity of their students thus promoting a culture of dialogue. The result obtained in the analysis can be an incentive to think thorough when creating curricula for educating teachers, both in initial and life-long learning so that they promote intercultural values.
\end{abstract}

Keywords: Bosnia and Herzegovina, intercultural education, Serbia, teacher trainee.

\section{Introduction}

A crucial challenge that modern Europe must face is the interactions between different people, ethnic and religious groups and minorities and movements that make up the diverse mosaic of their societies (Beljanski et al., 2016). The main questions are how to deal with differences and coexist peacefully and constructively in the multicultural world while simultaneously developing a sense of community, belonging and the wholesome development of students, first at school and then in the society as well. For this, intercultural competences, as well as teachers who are equipped for developing these competencies in students, are needed (Mrnjaus \& Rončević, 2012). Competence in intercultural interaction has been repeatedly emphasized, and competence in intercultural interactions are essential needs for teachers who are preparing students for life and work in a modern, multicultural society (Zlatković \& Petrović, 2016; Halpern, 2017; Tarman \& Tarman, 2011). The multinational and

\footnotetext{
${ }^{1}$ Corresponding author E-mail: milabelj@gmail.com
} 
multicultural societies in which students will work in the future, and in which more extensive migrations and contacts with different cultures are to be expected, will demand a highly developed intercultural competence for successful work in the field of teaching and pedagogy. In a modern classroom environment, interculturality or education of acceptance is a crucial principle.

The focus of this paper is on the importance and significance of interculturality in the education of future lower primary teachers in general, as a chance that the future teachers will be the initiators and activists in addressing cultural differences in the society and active participants in battling prejudices, stereotypes and barriers. School programs organized according to multicultural principles are accepted to be the dimensions of multicultural education (Pena et al., 2018; Yilmaz, 2016) and multicultural education contributes to the critical thinking abilities and awareness of teacher candidates (Dietz, 2018). In this way, they will help raise responsible people with a developed skill of shared life and ready to accept differences. This type of teacher would also create opportunities within the curricula to meet other cultures who would use those opportunities to develop openness and interculturality.

\section{Interculturality and Intercultural Education}

Interculturality is a must for relationships with other cultures. At the same time, multiculturality points to the fact that multiple cultures live one close to the other (ŠimonjiČernak et al., 2015). Multiculturality is the coexistence of multiple cultures as shared space, while interculturality is the relationship between cultures and their interactions. Although European societies are becoming increasingly multicultural, that does not necessarily make them intercultural. Some authors (Flores H \& Palacios Mena, 2018, p. 65) define interculturality as "the social capacity of a people to build their future, taking advantage of the lessons of their historical experience and the real and potential resources of their culture."

Intercultural education is a vital factor in the process of getting to know one another, understanding different cultures and establishing positive relations. Intercultural education has two key dimensions: acknowledgment of differences and respect for human rights. For the process of intercultural education to be successful, we need to get to know our own culture first before we meet the cultures of others (Nikšić Rebihić \& Dedić Bukvić, 2019). Some authors suggest that the primary aim of intercultural education is to enable every child to play a fully participatory role in the society (Wereszczyńska, 2018), ensure sustainable social cohesion, sustainable social and cultural capital development, and sustainable development of well-being especially for vulnerable individuals and groups (Sorkos \& Hajisoteriou, 2020).

A notable characteristic of intercultural education is education about attitudes, abilities, emotions, the way of being and communicating with a person from a different culture, who is different from us. Being brought up in an intercultural way means to communicate, but also to listen to "the other" (Jevtić \& Petrović, 2012). In this context, others and those considered to be different are groups of children from socially marginalized families, with poor social-economic status, children of divorced parents, children without parental care, children with developmental difficulties as well as children with socially unacceptable behavior. Given that a teacher is sensitive regarding these cultural differences and has a positive view of the students of different backgrounds, then he or she is ready to teach students how to communicate and accept those who are different and make them feel like equal members of the community. They can create an anti-discriminatory environment and, at the same time, hold the values of their own culture (Dedić Bukvić \& Sadiković, 2019; Polat, 2020). 


\section{Intercultural Competences}

Building a society in which there are equal opportunities for all, requires individuals who are ready to coordinate their needs with the needs of others, to come to decisions while respecting the tradition, customs and values of their own and those of others. School plays a crucial role in creating such a climate in which every student will feel well and will have respect for differences. Teachers are also an essential link in this task. If teachers are sensitized for acknowledging and accepting other cultures with knowledge and respect for their own culture, then he or she will pass this on to his or her students and make every student feel respected and acknowledged. They are there to alter misconceptions of the students regarding social, cultural and educational issues and to persuade them to take action in response to intercultural challenges that they experience in their lives (Delante, 2020). Study programs at teacher's colleges and faculties of education should provide the information and experience needed for contemporary education, including intercultural education or teaching acceptance. Therefore, teacher's colleges and faculties of education play a crucial role because a modern approach to education and modern curricula demand a large number of teachers' competences so they can realize the planned goals and objectives in their jobs (Zlatković \& Petrović, 2016) and provide education in the mother tongue, a reconstruction of the educational system, ensuring the social integration, and survival of local values through education (Robbins et al., 2019; Sylaj \& Sylaj, 2020; Yilmaz, 2016).

Intercultural competence has become increasingly critical in recent decades with the effects of globalization, population mobility and internationalization of education. With the arrival of culturally different students, schools have been facing one of the most critical changes in their history. The position and role of educators in modern schools entail intercultural competences (Deardorff, 2006). Possessing intercultural competences means being capable of living in the conditions in which every individual is accepted regardless of their original culture, lifestyle or cultural background (Nikšić Rebihić \& Dedić Bukvić, 2019).

According to Kuzmenko and Goncharenko (2007), an educator with intercultural competences is someone who can see and understand the relationships between cultures, understand and grasp the beliefs and behavior of members of different cultures as well as act in a constructive way in dealing with matters of social importance. If a teacher possesses multiple cultural knowledge, then he or she can use the knowledge of the practical customs of the multicultural region in the teaching practice (choice of teaching materials, forms and methods of working with students). They are also able to understand a student's inner world, emotional firmness and have a love for children, kindness, and responsibility, among others.

\section{Intercultural Education in Serbia}

Nonetheless, intercultural education in Serbia has not yet become an integral part of the country's comprehensive school program. Still, it often exists as singular examples of content, concepts or topics added to the curriculum without changing its original structure. Education about world cultures, religions and traditions are included in the curricula of particular school subjects (history, geography, literature, foreign languages, music and arts). The literature classes include texts written by minority authors, leading to the conclusion that opportunity exists for students to learn about different cultures because intercultural education is a process in which we learn about living together in the world of differences. This makes it a starting ground for nurturing understanding, acceptance and mutual respect (Beljanski et al., 2016; Bucther et al., 2020; Vu, 2019).

Organizing classes in a mother tongue and providing an opportunity to learn "the language of the immediate surrounding" (students from majority groups learn the languages 
of minorities) represents an essential contribution to intercultural understanding and fulfillment of minority group human rights. When it comes to the language of teaching, the law in Serbia stipulates that teaching is done in the mother tongue. In the areas in which there are national minorities, education at all levels can be done in the language of the minority, depending on the demand and availability of teaching staff. For example, in pre-school, elementary and secondary levels (and partially in high and higher education), there is a complete education system in the languages of minorities. When teaching is done in the language of minorities, textbooks and other teaching resources are regulated by law. Members of the national minorities in education can use textbooks from their motherland, according to the provisions of the Ministry (Law on the Fundamentals of Education System, 2019). Developing programs for the integration of intercultural perspective in the whole of the education system is essential. Programs need to include different subjects, after-school clubs and activities, and a school ethos aimed towards the community.

A systematic approach, such as incorporating interculturality into the education system (intercultural education reform) means, primarily providing systematic support to teachers and schools to administer and follow a particular curriculum (Beckett \& Kobayashi, 2020; Nikolić, 2019; Wilcox, 2020). Teacher training for working with different groups has not yet been systematically organized nor is it mandatory. It is, as a rule, introduced into few schools, usually by NGOs (Guide to Intercultural Education, 2017). Therefore, it would be of considerable significance to raise awareness about the importance of this topic as early as possible in teachers' colleges and faculties of education. In these very places, future teachers are being taught how to do their profession. Knowledge, attitudes and skills that would be the foundation of interculturality and intercultural competences for future teachers and would, later on, reflect on searching for and implementing the contents that represent the connection of cultures, the development of interculturality should be included. When educating members of minority groups, actual bilingual institutions and programs that include members of both minority and majority groups to develop good inter-ethnic relationships and better social cohesion and integration should be developed if possible (Education Strategy, 2012). Even the education strategy, which is an important document helping to create real values and then putting them into practice, does not have an articulated goal, does not list possibilities, and the need for implementing interculturality. We should work on raising awareness about the importance of living together with different ethnic, religious and social groups.

\section{Intercultural Education in Bosnia and Herzegovina}

When intercultural sensitivity, intercultural identity and intercultural competences are developed, a student is more than ready to deal with current living conditions. Intercultural education provides opportunities for developing a modern member of the society, who is not only a member of a single community but a citizen of the world. Educating citizens of Bosnia and Herzegovina to be citizens of the world is not well designed, nor is intercultural education systematically planned. Complicated administration of the education system contributes further to this problem. Education responsibilities are divided into two entities (Federation of Bosnia and Herzegovina and the Republika Srpska) and a separate organizational unit Brčko District. Within the Federation of Bosnia and Herzegovina, the actual responsibility is dispersed among ten cantons. This means that thirteen subsystems in the territory are under the governance of the Ministry of Civil Affairs of Bosnia and Herzegovina (OSCE, 2018; UNICEF, 2017). General aims of education that are represented in the Framework Law on Primary and Secondary Education in Bosnia and Herzegovina (2003) (Official Gazette of Bosnia and Herzegovina 18/3) emerge from conventional, universal values of a democratic society, as well as personal value systems based on the national-specific, historical, cultural and religious tradition of people and minorities living in Bosnia and Herzegovina. 
The challenges to this are present in the fact that there are "two schools under one roof," which was viewed as a temporary measure to answer the ethnocentric situations in education. However, this temporary solution became permanent and is still leading to the segregation of certain ethnic groups in Bosnia and Herzegovina. Classes are taught following curricula and textbooks that are nationally biased and share a negative perspective of some constituent nationalities in Bosnia and Herzegovina (UNICEF, 2010). Strategic documents for education reform in Bosnia and Herzegovina accent respect for human rights, equal possibilities for all and interculturality (Soldo et al., 2017). Nonetheless, the scheme of things with "two schools under one roof" is not only in direct opposition with the Strategy of the reform of education in Bosnia and Herzegovina, but also international obligations that Bosnia and Herzegovina accepted and domestic legislation in terms of education (OSCE, 2018, p. $10)$.

Mandatory schoolbooks that students use in Bosnia and Herzegovina are often defined through political, ideological and cultural dimensions. The same authors propose that textbooks have implicit dimensions as well, which means that they are subject to value and cultural context. This contributes to textbooks being in a grey zone between society and family, science, propaganda, individual subjects and comprehensive education. For instance, history books manipulate the ideology and focus on one ethnic group as showing "our truth" (Radušić, 2015). Even though some change has occurred in the teaching of subjects of a national group of subjects, no unified approach exists. Open Society Fund Bosnia and Herzegovina and proMENTE Social Research conducted research in 2007, and then, ten years later, to determine and define fundamental values that the education system of Bosnia and Herzegovina promotes given the example of a national group of subjects (geography, history, language and literature, religious education). The results showed that textbooks in the national group of subjects contribute to segregation, developing discriminatory attitudes, boosting certain ethnic groups, and avoidance of humanistic ideas and principles (Soldo et al., 2017).

Working on the reform of curricula and harmonization with the fundamental principles of education represents a crucial step in creating inclusive schools with no discrimination. In the education system of Bosnia and Herzegovina a teacher needs to have intercultural competences and be capable of answering the demands of education showing respect for and acknowledging the rights of every student, creating anti-discriminatory and inclusive community, promoting duties of establishing a relationship with others and acting in the best interests of students.

\section{Methodology}

The aim of the present paper is to analyze the existing curricula for educating teachers at the state-owned universities in Serbia and Bosnia and Herzegovina and establish the presence of subjects and educational content related to intercultural education.

For the purpose of this research, official documents were used (a total of 12 curricula) taken from digital platforms of public universities (a total of 12 public institutions for educating future teachers in Serbia and Bosnia and Herzegovina in the 2018-2019 academic year). The starting point of the research included the following questions:

1. Which subjects are there in the current curricula for teaching future primary school teachers which include opportunities for developing intercultural competences?

2. How many hours are dedicated to lectures, practice or seminars within the subjects in the area of intercultural education? 
3. How many ECTS (European Credit Transfer and Accumulation System) credits are awarded for subjects which allow opportunities for developing intercultural competences?

4. Which subjects in the area of intercultural education are optional and which are mandatory?

For achieving the set goals of the research, content analysis was used in which curricula were taken from the faculties of education of future primary school teachers. The curricula were relevant for the academic year of 2018-2019. Furthermore, a descriptive method was used to recognize and interpret contents from the area of intercultural education, as well as classes dedicated to important subjects. This method was used for interpreting and analysis of the results of the research. This paper worked with documents using a data analysis matrix.

The sample for this research was made up of national documents that regulate tertiary education in Serbia and Bosnia and Herzegovina, as well as curricula of public universities of the states above, which were relevant for the 2018-2019 academic year in the following institutions:

- Serbia:

- Curriculum of the Teacher Education Faculty, University of Belgrade;

- Curriculum of the Faculty of Education in Sombor, University of Novi Sad;

- Curriculum of the Faculty of Education in Jagodina, University of Kragujevac;

- Curriculum of the Faculty of Education in Užice, University of Kragujevac;

- Curriculum of the Faculty of Education in Vranje, University of Niš;

- Curriculum of the Teachers' Training Faculty in Leposavić, University of Priština.

-Bosnia and Herzegovina

- Curriculum of the Faculty of Educational Sciences, University of Sarajevo;

- Curriculum of the Faculty of Philosophy of the University in Banja Luka;

- Curriculum of the Faculty of Education of Džemal Bijedić University of Mostar;

- Curriculum of the Faculty of Science and Education of the University of Mostar;

- Curriculum of the Faculty of Philosophy in Tuzla;

- Curriculum of the Faculty of Pedagogy of the University of Bihać.

\section{Analysis and Interpretation of the Research Results}

\section{Bachelor Studies- Serbia}

The curricula of the teaching and education faculties in Serbia that were under analysis differ in many aspects. One was the total number of courses in the four years of studies (i.e. eight semesters). Furthermore, there are differences in the categorization of the number of courses within academic-educational, scientific or artistic courses. A different approach can be seen concerning the titles of the courses and their content. Also, some courses were mandatory in certain faculties. In contrast, they were optional in others (e.g., Introduction to Andragogy is mandatory in Leposavić, while it was optional in Vranje and Užice). Moreover, a different number of courses were present in certain areas of study (e.g., humanities, literature, information science, natural sciences, methodology, skills, etc.). Due to these differences, the contents of all the courses and all syllabi, which were available on the faculty websites, were analyzed. Such an analysis represents an initial attempt to analyze all curricula 
of the faculties educating future teachers in two countries to ascertain the degree of the presence of courses that implement, in direct or indirect form, intercultural education. Also, it is important to tag those courses that do not explicitly state their intercultural character but should. The analysis undertaken does not provide ample evidence and insight into the realization of the courses and curricula nor the achieved outcomes for those courses. Nevertheless, a possibility exists that in the actual lectures or classes, intercultural content emerges, which aligns with the goals of intercultural education. However, no way of determining this exists, and in the end, it is not pertinent to this analysis.

The analysis of the curricula of the faculties that educate future teachers has shown an inconsistent and insufficient ratio of intercultural education at the level of undergraduate studies. Only two of the faculties in Serbia have a course titled Intercultural Education (Jagodina and Vranje). These are optional courses in the first and third year of undergraduate studies. The analysis has shown that the number of ECTS credits awarded also differs for these two courses (5 ECTS credits in Jagodina and 3 ECTS credits in Vranje).

Most of the courses that have been listed as those containing intercultural education do not have it directly listed in their course content. Those conclusions can be drawn through outcomes. The number of these courses is different, ranging from 18 to 3 , in which the intercultural contents are not explicitly given, but some elements supporting the idea of intercultural education are presumed. Such is the course of Civics Education, which is mandatory in Sombor or optional in Užice, Leposavić and Vranje. At the same time, it does not exist in the remaining two faculties. Courses from the field of sociology are present in all faculties that educate future teachers. Courses such as sociology, or sociology of education, as mandatory courses and those such as sociology of everyday life, a theory of anthropology, culture and society have in their outcomes topics related to interculturality (education and social inequality; familiar relationships and transferring cultural values and patterns; the role of education in disseminating culture, developing strategies to help students from disparaged groups and others), which leads to the conclusion that there should be some notion of interculturality. Also, it is a matter of the skillfulness of the teacher who teaches these courses to use the given opportunities for getting to know their own culture and other cultures.

Subjects in the field of philosophy lend themselves perfectly to this. Philosophy is one of the mandatory courses at faculties (Philosophy and Ethics in Belgrade and Leposavić), while at other faculties ethics is among the optional courses (Sombor, Užice, Vranje), with Philosophy of Education (Belgrade), Introduction into Logic and Scientific Methods (Belgrade), Rhetoric (Užice), and Logic (Užice, Sombor). Course contents within this group of courses also list respect and tolerance of cultural differences among people, mastering the skill of critical thinking, developing the culture of dialogue, problems of tolerance and equality, forming and supporting attitudes about the most significant social matters of gender, racial and national differences.

The analysis of the curricula points to the fact that several courses in the field of psychology contain units or modules of intercultural education. Namely, Developmental Psychology and Pedagogical Psychology are mandatory courses at all faculties. The array of optional psychology-related courses is vast. It varies from one faculty to another (depending on the availability of teaching staff, and the specialty of the faculty itself). These are courses in the field of communication, the psychology of communication, non-violent conflict resolution, advisory work, the psychology of giftedness, the psychology of education, etc. The contents of these courses list outcomes such as the development of abilities, attitudes, battling prejudices and stereotypes, social work within schools, development of social responsibilities of students, active listening, and non-violent conflict resolution.

Courses in the field of inclusive education, which are by nature of a multidisciplinary character, appear at all faculties educating future teachers. The analysis shows that this topic 
appears under various names: Pupils with Special Education Needs (Sombor), Inclusive Education (Jagodina), Methodology of Working with Children with Special Needs (Belgrade), Basics of Inclusive Education (Užice, Vranje), Individualization and Integration in Education (Vranje) and optional courses: Inclusive Teaching (Leposavić); Didactic Materials and Assistive Technologies in Inclusive Classroom (Sombor); Working with Gifted Students (Jagodina) and others. The analysis shows that most of the courses' content is similar, with minor differences and topics that are covered in more depth or analyze certain topics with more scrutiny. Also, within the courses themselves, there are many opportunities to develop the intercultural skills of teachers to be. However, without an insight into the implementation of the courses, we do not know whether these opportunities are used to develop the education of acceptance.

At the bachelor or undergraduate level of studies at all faculties educating future teachers, a group of courses in the field of pedagogy is present. All six faculties list these as mandatory: General Pedagogy (or Introduction to Pedagogy in Jagodina), School Pedagogy, Didactics, Methodology of Pedagogical Research (or Methodology of Research in Education, as it is named in Sombor). Also, in some of the faculties (Sombor, Jagodina), School and Family Pedagogy is a single course that is also mandatory. As far as optional courses go, the list is rather diverse and random but covers a large area of pedagogy: History of Pedagogy (Užice, Vranje, Belgrade), Docimology (Užice, Vranje, Belgrade, Leposavić), Andragogy (Užice, Vranje), Action Research (Užice), Methodology of Working in Mixed Classes (Užice, Sombor, Vranje, Leposavić), Working as a Form Tutor (Vranje), Special Pedagogy (Vranje, Belgrade), Didactic Games (Sombor), Pedagogy of Leisure Time (Jagodina), Pre-School Pedagogy (Leposavić), as well as other courses. Most of the courses are aimed at intercultural education, which is seen from the syllabi of these courses (Fostering Group Work, Working with Peers and Adults, educating trainees on how to care for the child according to their needs and abilities, nurturing tolerance towards differences in education styles).

The analyses of the syllabi have pointed to the fact that the number of lessons (lectures, practicals and other forms of work) is different for most courses in studied faculties (Zlatković \& Petrović, 2016) so there are noticeable differences in the number of lessons of lectures and practical lessons in the courses which in one way or another, implement contents of intercultural education. The weekly number of lessons, for example, (lectures and practical lessons) for an interdisciplinary course, of Civics Education with a large proportion of intercultural content was $2+1$ in Sombor. At the same time, Leposavić had 5 lessons in total $(3+2)$.

The analyzed courses show differences in terms of the value indicated by ECTS points. The same course, for instance, Developmental Psychology, which is one of the courses with elements of intercultural education, has values ranging from 4 credits (Sombor, Jagodina) to 8 ECTS credits(Užice).

Regarding other courses, their outcomes and content indicate different levels of intercultural education. There are no explicitly listed topics connected to intercultural education, though there should be because these present opportunities for developing interculturality. These are manly humanities, but there are other examples of literature (such as Russian Culture, History of French Civilization, Creative Activities for Serbian Language Classes in Belgrade). Most of these can be found at all faculties (history, methodology of lower-level science classes), while a smaller number of courses can be found at a single faculty at the time, or only a few of them (Basics of Children's Dances-optional course, 3 ECTS points, Classroom Management-Sombor, optional 6 ECTS points). Such is the nature of the course Intermediate French Language in Jagodina, worth 5 ECTS points, where the outcomes of the course state that "students understand basic elements of the French culture and culture of other francophone countries, can analyze them and compare to the elements of one's own culture." Also, at this faculty's third-year studies, there is an optional course, 
Elementary Musical Instruments, worth 5 ECTS credits that provides opportunities for sensitization because a possibility exists for creating a class topic to compare typical musical instruments of minorities, which is a direct example of intercultural education.

\section{Master's Level Studies - Serbia}

In the curricula regarding education and training of future teachers at the master's level in Serbia, few intercultural topics, areas or units of study are overtly stated. Results show that at the Teachers' Training Faculty in Leposavić, Teacher Education Faculty in Belgrade and Faculty of Education in Užice, there are no individual courses labeled as intercultural. Other intercultural content is not explicitly listed in other courses based on the analyzed syllabi in the course list booklet.

At the Faculty of Education in Sombor, at the master's studies, there is a course named Intercultural Education as an optional course (worth 6 ECTS points, two classes of lectures and two practical classes). Also, there are other optional courses such as Methodology of Civics Education 2, Contemporary Methodology of Humanities 2, with the same ECTS credits allocated and the same class load as the Intercultural Education course. The content shows that the topics are, to a certain degree, related to intercultural education. They include acknowledging differences and particularities, overcoming gender, age, behavior, appearance and background stereotypes, rules of life in a community, local population (similarities, differences, coexistence).

At the Faculty of Education in Jagodina, there are two courses within the master's degree studies that are linked to intercultural education. There are two mandatory courses, Inclusive Education- Theory and Practice (4 ECTS points, 2 classes of lectures and two practical classes per week as well as an optional course Culture and Society (5 ECTS credits and 2 classes of lectures, 1 practical class per week). The expected outcomes revolve around acquiring a positive attitude towards all children equally as well as students as future teachers having the ability to influence the process of socialization of children's culture significantly, i.e., the development of a child's self-awareness and his or her interaction within a group.

At the Faculty of Education in Vranje, at the master's level, the analysis found two courses with present elements of interculturality. These are Serbian National Culture in the European Context (5 ECTS credits, 2 classes of lectures and 2 classes of practical studies). The outcomes of this course state that the teacher trainees will acquire knowledge that will enable them to improve their professional capacities, understanding and tolerance based on knowledge and respect for other cultures and individuals, i.e. intercultural competence. Another optional course, Chosen Topics from the Methodology of Musical Education (6 ECTS credits, 2 lecture classes and 2 practical classes per week), also implements topics that can be related to intercultural education. This course represents an opportunity for nurturing interculturality, for one of the topics covered is getting to know the musical heritage of other nations.

The analysis of the syllabi at the level of the academic studies at the master's degree shows that more courses should cover intercultural education. Although intercultural competences and interculturality are somewhat developed through the existing courses at the teacher training faculties, the existing syllabi and the goals and outcomes of the courses do not show an ample opportunity for the development of these competencies. Perhaps there are more courses in which interculturality is mentioned. Perhaps this topic is covered in lectures and practical classes. Still, it is not listed as such in the catalog. 


\section{Education of Primary School Teachers in Bosnia and Herzegovina}

Tertiary education in Bosnia and Herzegovina is conducted at eight universities. The Federation of Bosnia and Herzegovina has the following public universities: The University of Sarajevo, Džemal Bijedić University in Mostar, the University of Mostar, the University of Zenica, the University of Tuzla and the University of Bihać. In Republika Srpska, tertiary education is conducted by two public universities: The University of Banja Luka and the University of East Sarajevo.

An analysis of the curricula that had been implemented in the 2018-2019 academic year at all faculties for the education of future teachers found vast differences in teaching intercultural content, which, in some cases, is the effect of the difference in the very structure of the educational system.

This current study identified three courses that contained the word "intercultural" in their titles, namely, the courses named Intercultural Understanding, Human Rights and Peaceful Conflict Resolution, which were part of the syllabus of the lower elementary teacher training course at the Faculty of Education in Sarajevo, followed by Intercultural Education as part of the syllabus of lower elementary teacher training at the Faculty of Sciences and Education of the University of Mostar, as well as Intercultural Pedagogy at the Teacher Training Faculty at the University of Zenica. These courses were offered as optional in all the curricula. Contents of the course Intercultural Understanding, Human Rights and Peaceful Conflict Resolution is taught by delivering one class of lecture and one class of practical training per week and is awarded 2 ECTS credits. The course Intercultural Pedagogy taught at the University of Zenica has two classes of both lectures and practical training and is awarded 4 ECTS credits. These are all examples from the first cycle of studies. The course Intercultural Education is taught in the second cycle of studies. It is conducted through two classes of lectures and two practical classes. It is awarded 4 ECTS credits.

Intercultural course contents are also present in the courses in the field of general pedagogy which are listed in the curriculum of the first cycle of education of lower elementary teachers of the University of Sarajevo, namely, General Pedagogy 1, which is taught by delivering two classes of lectures and one practical lesson per week. This course is awarded 4 ECTS credits.

The group of courses in the field of psychology at the teacher training faculties in Bosnia and Herzegovina, contain the following courses: Developmental Psychology 2 at the University of Sarajevo and Psychology of Education at the University of Bihać. For the two classes of lectures and one practical class taught at the first study cycle at the University of Sarajevo for the course Developmental Psychology 2, students are awarded 3 ECTS credits. In comparison, the contents of the course Psychology of Education at the University of Bihać, which is awarded 4 ECTS credits, are taught at the first cycle of studies and include three classes of lectures and one seminar and.

Courses that cover key aspects of intercultural education such as human rights, understanding, respect for the rights of others, acknowledging and understanding of the guaranteed rights, respect of the differences and other, are the following: Civics Education with Methodology, Civics Education, Methodology of Civics Education, Democracy and Human Rights, Education for Democratic Society, and Education for Democracy. These courses are found in the curricula of the faculties educating teacher trainees in Sarajevo, Mostar, Zenica, Tuzla and Banja Luka. In most cases, there are two classes of lectures, except for the course Education for Democracy with four classes of lectures and two practical classes. More often than not, the courses are awarded 4 ECTS credits, except Civics Education with Methodology, which is awarded 2 ECTS credits. These courses are all found in the first study cycle. They are a part of the curricula of the public universities in Bosnia and Herzegovina. 
Courses in the field of inclusive education also have topics covering the development of intercultural competences of the future lower level primary school teachers. Intercultural topics are covered by the course Inclusive Classes at the Teacher Training Faculty in Mostar, which includes two classes of lecture and one practical class per week. The course is awarded 4 ECTS credits. The University of Mostar also offers a course Pedagogy for Children with Special Educational Needs. The contents of this course are taught by delivering two classes of lectures and seminars alike and the course is awarded 5 ECTS credits. At the Teacher Training Studies in Zenica, the course Inclusive Education is also available. The curriculum of the faculty in Tuzla, on the other hand, offers the course Pedagogical and Social Aspect of Inclusion. The course Inclusive Education has two classes of lectures and two practical classes. It is awarded 4.5 ECTS credits, while the course Pedagogical and Social Aspect of Inclusion has three classes of lectures and one practical class and is awarded 6 ECTS credits. Inclusion in Education is a course at the University of Banja Luka that offers intercultural topics to future teachers and includes one class of both lectures and practical classes per week. Pedagogical and Social Aspect of Inclusion and Inclusion in Education are found in the second cycle of studies, while all other courses listed here are found in the first cycle of studies.

In the field of sociology, several courses foster intercultural competences of future teachers in the lower primary schools. These are Sociology of Education at the University of Tuzla and the University of Bihać. At the University of Tuzla, the course is awarded 4 ECTS credits, while the University of Bihać awards it 3 ECTS credits. Both courses are conducted through two classes of lectures and one practical class per week. Apart from these two, there are two more courses of the same title, Sociology of Education at the University of Banja Luka and the University of East Sarajevo. The course Sociology of Education, which is taught at Teacher Training Studies at the Faculty of Philosophy in Banja Luka, has three classes of lectures and one practical class and is awarded 5 ECTS credits. On the other hand, the course of the same title taught at the Teacher Training Studies at the Faculty of Philosophy at the University of East Sarajevo has two classes of lectures and 3 ECTS credits.

The courses from the domain of philosophy that are part of the curricula of the teacher training institutions in Bosnia and Herzegovina are optional courses such as the Theory of the Value Systems at the University of Sarajevo, Introduction into Ethics and The Culture of Dialogue at Džemal Bijedić University in Mostar, which have two classes of lectures and one practical and seminar class. At the University of Mostar, Philosophy of Education and Ethics are mandatory courses for teacher trainees. These courses have two classes of lectures and practicals. Furthermore, it is worth mentioning two more courses: Ethics at the University of Zenica and Ethics in Education at the University of Banja Luka. This university also offers the course Philosophy of Education and includes one class of lectures and one class of practicals. Philosophy of Education, which is also taught in Bihać, has two classes of lectures and one class of practicals. These courses are awarded 2, 3, or 4 ECTS credits, respectively.

An optional course at the Faculty of Education at the University of Sarajevo is the Cultural Heritage of Bosnia and Herzegovina. Future teachers studying this course are examining their own identity, understanding cultures in Bosnia and Herzegovina, as they explore values of cultural and historical heritage, among others. This course has one class of lectures and one class of practicals and is awarded 2 ECTS credits.

Based on the analysis of the curricula of public universities in Bosnia and Herzegovina education of future teachers, the conclusion can be reached that intercultural content is not present to a large degree. It is, in fact, present in only one course at the basic academic level at the University of East Sarajevo, and three courses on offer at the University of Mostar, followed by four courses at the Universities of Bihac and Zenica. The largest number of such courses is offered by the University of Banja Luka and Dzemal Bijedic University in Mostar, 
i.e. five courses in total. Only the University of Sarajevo offers as many as six courses that foster the development of intercultural skills.

\section{A Comparative Overview of the Intercultural Education of Future Teachers in Serbia and Bosnia and Herzegovina}

The education of future teachers in Serbia and Bosnia and Herzegovina is conducted at twelve different public institutions of higher education. The education process is conducted in accordance with the Bologna process principles, at the first cycle (bachelor or undergraduate studies), second cycle (master's studies) and third cycle (doctoral thesis). This paper analyzes the first and second cycles of studies in connection with intercultural studies of teachers in Serbia and Bosnia and Herzegovina.

Education of future teachers at public universities in Serbia and Bosnia and Herzegovina is conducted in two cycles of studies, within the first cycle of four years or eight semesters and the second cycle of one year, or two semesters. As per available information on the websites of the given institutions, only the University in Bihać and the University of Zenica do not offer the possibility of studying at the second cycle for future teachers. Other public studies in Serbia and Bosnia and Herzegovina offer graduate or master's level studies for future teachers.

The analysis of the curricula found that only two courses in the public universities studies in Serbia and Bosnia and Herzegovina contained the term "intercultural" in their course names, which are offered to future teachers as in the course of five-year studies to develop intercultural competences of future teachers. However, there are ample opportunities within various courses that allow students to study particular areas of intercultural education. These courses have been grouped into the following categories in this paper: pedagogy, psychology, inclusive education, sociology and philosophy. Within these groups, this study has singled out courses that offer intercultural education within their syllabus. These are Family Pedagogy, General Pedagogy, School Pedagogy, Didactics, Methodology, and other courses from the field of pedagogy, followed by Psychology of Education, Developmental Psychology and other courses from the area of psychology, which foster, through their content, intercultural dialogue, mutual understanding, coexistence, respect, non-violent communication, building attitudes and diminishing prejudices and other essential skills that are significant for intercultural education. The content of the courses from the sociology and philosophy groups tap into areas such as ethics, civics education and others, which help teachers to develop their intercultural competences. The area of inclusive education offers content that nurtures respect for the different, fairness in education, sensitivity, and developing skills for creating inclusive environments. Apart from these groups, others have been identified as well in the area of humanities and arts that also offer opportunities for intercultural education of future teachers.

The analyzed and interpreted curricula do not, in reality, offer any insight into an actual teaching process. Therefore, we cannot speak of the style of teaching university students in becoming teachers, nor whether the actual topics are covered in the lectures. However, we believe that university lecturers and professors can offer opportunities to their students to develop intercultural competences using the content provided in the courses, their teaching style and their persona as role-models.

The current study presents some limitations, mainly due to its inability to review lesson reports that would best showcase the usage of intercultural opportunities. As this study was the first-of-its-kind in the region and set up as a pilot cross-sectional study, the obtained results could be considered as a significant guideline for the design and implementation of further research. It would be interesting to examine intercultural sensitivity of teachers in these two countries that have a heterogeneous structure of both teaching staff and students. 
Previous research (Yilmaz, 2016) evaluated the concept of intercultural education on the basis of differences and stated that the social structure is not homogenous, that different structures coexist and they care about multicultural education so that these structures can protect their integrity and survive, so research of this kind would be invaluable.

\section{Conclusion}

The result obtained from the analysis could be taken under advisement when creating curricula for educating teachers, both in initial and life-long education so that they promote intercultural values.

The analysis and description of the curricula have provided data which indicate that intercultural elements are insufficiently represented. This calls for a reconceptualization of the curricula. Therefore, we wish to underscore the importance of having a systematic intercultural education of teachers. Only a competent teacher will organize activities related to leading another individual and his or her own activity in realizing his or her full potential as well as the totality of affecting factors and functions formulating and regulating one's personality and behavior in relation to other people and to the world (Flores \& Palacios Mena, 2018). In order to engage in intercultural interactions, one must be open to an idea of others and otherness. This is why it is crucial that teachers are educated about intercultural values and become competent in intercultural interaction, so that they continue to serve as a bridge over which they guide their students to cross, and having facilitated their crossing, encourage them to craft their own future (Delante, 2020). Competent teachers will create a positive environment for proper intercultural communication and develop the intercultural sensitivity in their students, promoting a culture of dialogue. Such teachers put effort into promoting intercultural values in their classroom, building a brighter future for new generations in the post-conflict zones.

One task of a school should be studying intercultural education that will be reflected in acknowledging differences and their value and models of living. Cultural differences and their role in everyday life are inherently reflected in students' behavior at school asteachers shape and transfer intercultural knowledge to their students. If teachers have developed their intercultural competences in their initial education and work and keep developing them later on, then they can create an intercultural environment for their students and prepare them for future challenges.

\section{References}

Beckett, G. H., \& Kobayashi, M. (2020). A Meta-study of an Ethnographic Research in a Multicultural and Multilingual Community: Negotiations, Resources, and Dilemmas. American Journal of Qualitative Research, 4(1), 85106. https://doi.org/10.29333/ajqr/8267

Beljanski, M., Velišek-Braško, O., \& Šimonji Černak, R. (2016). Čitanka u osnovnoj školi u funkciji razvoja interkulturalnosti [Textbook in elementary school as a tool for developing interculturality]. In D. Radović \& E. Toldi (Eds.), Interkulturalnost $u$ obrazovanju [Intercultural in education] (Zbornik 10, pp. 35-49). Pedagoški zavod Vojvodine.

Buchter, J., More, C., Oh-Young, C., \& Stringfellow, J. (2020). Disrupting Norms to Increase Diversity of Teacher Candidates: Restraining Forces for Junior Faculty. Journal of Culture and Values in Education, 3(1), 89-103. https://doi.org/10.46303/jcve.03.01.6 
Deardorff, D. K. (2006) Identification and assessment of intercultural competence as a student outcome of internationalization. Journal of Studies in International Education, 10(3), 241-266. https://doi.org/10.1177/1028315306287002

Dedić Bukvić, E., \& Sadiković, A. (2019). Pogled na interkulturalne dimenzije u nastavi: Nastava namijenjena svim učenicima, a ne samo kulturalno različitim [View of the intercultural dimensions of teaching: Teaching for all students, not just culturally different]. In Zbornik radova, Pogled u svijet obrazovanja, nauke $i$ mladih [Proceedings, A look at the world of education, science and youth] (pp. 251-266). Pedagoški fakultet Univerziteta u Sarajevu.

Delante, N. (2020): Classroom teaching as an intercultural communication phenomenon: A thematic analysis of a foreign teacher's rhetorical practices as communication dynamic. Journal of Intercultural Communication Research. https://doi.org/10.1080/17475759.2020.1790406

Dietz, G. (2018). Interculturality. The International Encyclopedia of Anthropology. https://doi.org/10.1002/9781118924396.wbiea1629

Flores H., I. A., \& Palacios Mena, N. (2018). Cultural and intercultural education: Experiences of ethnoeducational teachers in Colombia. Australian Journal of Teacher Education, 43(7). http://dx.doi.org/10.14221/ajte.2018v43n7.4

Halpern, C. (2017). Book Review: In search of understanding: The case for constructivist classrooms. American Journal of Qualitative Research, 1(1), 32-36.

Jevtić, B., \& Petrović, J. (2012). Interkulturalno obrazovanje sa pogledom na budućnost [Intercultural education with the view of future]. In Nauka i savremeni univerzitet [Science and modern university] (pp. 25-36). Filozofski fakultet. file:///D:/Radovi/Projekat\%20sa\%20Slovacima/Dobri\%20radovi\%20interkulturalnost/ 2._Bisera_Jevtic\%20interkulturalnost.pdf

Kuzmenko, V., \& Goncharenko, L. (2007). Polycultural competence as component of professional competence of pedagogue. In Zbornik radova: Kompetencije $i$ kompetentnost učitelja (pp. 287-293). Osijek.

Mrnjaus, K., \& Rončević, N. (2012). Interkulturalna osjetljivost i interkulturalne kompetencije budućih pedagoga, odgajatelja, učitelja i nastavnika - studenata Sveučilišta u Rijeci [Intercultural sensitivity and intercultural competences of future pedagogues, kindergarten and school teachers] In N. Hrvatić \& A. Klapan (Eds.), Pedagogija i kultura (pp. 314-321). Hrvatsko pedagogijsko društvo.

Nikolić, S. (2019). Interkulturalna transformacija škole u Republici Srbiji - singnifikantna regulative [Intercultural transformation of schools in the Republic of Serbiasignificant regulation]. In Društvene i humanističke studije (2nd ed., pp. 365-384). Filozofski fakultet u Tuzli.

Nikšić Rebihić, E., \& Dedić Bukvić, E. (2019). Interkulturalne dimenzije habitusa savremenog učitelja [Intercultural dimension of a contemporary teachers' habitus]. In Društvene i humanističke studije (3rd ed., pp. 177-194). Filozofski fakultet u Tuzli.

Okvirni zakon o osnovnom i općem srednjem obrazovanju [Framework Law on Primary and secondary Education in Bosnia and Herzegovina]. (2003). Službeni list Bosne $i$ Hercegovine (Report No 18/3). http://www.sluzbenilist.ba/

OSCE. (2018). "Dvije škole pod jednim krovom": Najvidljiviji primjer diskriminacije u oblasti obrazovanja u Bosni i Hercegovini ["Two Schools Under One Roof” - The most visible example of discrimination in education in Bosnia and Herzegovina]. OSCE. Mission to Bosnia and Herzegovina.

Peña, C., Jones, L., Orange, A., Simieou, F., \& Márquez, J. (2018). Academic success and resiliency factors: A case study of unaccompanied immigrant children. American Journal of Qualitative Research, 2(1), 161-181. 
Polat, S. (2020). Multidimensional Analysis of the Teaching Process of the Critical Thinking Skills. Research in Social Sciences and Technology, 5(2), 134-157. https://doi.org/10.46303/ressat.05.02.8

Radušić, E. (Eds.). (2015). Zloupotreba istorije u procesima koji su doveli do posljednjeg rata $u$ Bosni i Hercegovini [Abuse of history in the processes that led to the last war in Bosnia and Herzegovina, Framework for paradigm changes in teaching history in schools in Bosnia and Herzegovina]. Udruženje nastavnika i profesora historije /istorije/povijesti Bosne i Hercegovine - EUROCLIO HIP Bosnia and Herzegovina.

Robbins, C., Bishop, J., \& Tarman, B. (2019). Against Reactionary Populism: Opening a Needed Conversation in Education. Journal of Culture and Values in Education, 2(3), i-vi. https://doi.org/10.46303/jcve.03.02.ed

Šimonji-Černak, R., Beljanski, M., \& Marković, S. (2015). Education of Slovaks in Vojvodina as a factor of intercultural development. In L. Porubský (Ed.), Kurikulárna reforma a perspektívy základnej školy (pp.146-157). Univerziteta Mateja Bela v Banskej Bystrici, Pedagogická fakulta.

Soldo, A., Salibašić, A., Marshall, A., Šabotić, D., Radušić, E., Bičo, F., Forić, M., Ibrahimović, N., Hadžiab, N., Veličković, N., Buljević, S., Momčinović, Z.P., \& Smajić, Z. (2017). Obrazovanje u Bosni i Hercegovini: Čemu (ne) učimo djecu: Analiza sadržaja udžbenika nacionalne grupe predmeta u osnovnim školama [Education in Bosnia and Herzegovina: What we DO NOT teach our children: Analysis of the national group of subjects in elementary schools]. Školegijum.

Sorkos, G., \& Hajisoteriou, C. (2020): Sustainable intercultural and inclusive education: Teachers' efforts on promoting a combining paradigm. Pedagogy, Culture \& Society. https://doi.org/10.1080/14681366.2020.1765193

Strategija razvoja obrazovanja u Srbiji do 2020. godine. [Strategy for developing education in Serbia 2020]. (2012). Službeni glasnik Republike Srbije . (Report No. 107/2012). http://www.mpn.gov.rs/wp-content/uploads/2015/08/STRATEGIJAOBRAZOVANJA.pdf

Sylaj, V. Sylaj, A.K. (2020). Parents and Teachers' Attitudes Toward Written Communication and Its Impact in The Collaboration Between Them: Problem of Social Study Education. Journal of Social Studies Education Research, 11(1), 1-20. Retrieved from https://jsser.org/index.php/jsser/article/view/1649/435

Tarman, I. \& Tarman, B. (2011). Developing effective multicultural practices: A case study of exploring a teacher's understanding and practices. The Journal of International Social Research, 4 (17). 573-593.

UNICEF. (2010). Education in Bosnia and Herzegovina. UNICEF.

UNICEF. (2017). Analiza potreba nastavnika u pogledu stručnog usavršavanja i analiza budžeta za kvalitet u osnovnom i srednjem obrazovanju [Analysis of the teachers' needs for professional development and Budget analysis for quality in primary and secondary education]. UNICEF.

Vodič za unapređenje interkulturalnog obrazovanja [Guide to Intercultural Education]. (2017). Grupa Most.

$\mathrm{Vu}, \quad \mathrm{T}$. (2019). Theoretical Constructs and Practical Strategies for Intercultural Communication. Journal of Curriculum Studies Research, 1(1), 43-53. https://doi.org/10.46303/jcsr.01.01.4

Wereszczyńska, K. (2018). Importance of and need for intercultural education according to students: Future teachers. Polish Journal of Educational Studies. 1(71). https://doi.org/10.2478/poljes-2018-0017 
Wilcox, S. (2020). Policy Storms at the Central Office: Conflicting Narratives of Racial Equity and Segregation at School Committee Meetings. Research in Educational Policy and Management, 2(1), 40-56. https://doi.org/10.46303/repam.02.01.3

Yilmaz, F. (2016) Multiculturalism and multicultural education: A case study of teacher candidates' $\quad$ Cogent Education, 3(1). https://doi.org/10.1080/2331186X.2016.1172394

Zakon o osnovama sistema obrazovanja i vaspitanja Službeni glasnik Republike Srbije [Law on the Fundamentals of Education System]. (2019). Službeni glasnik Republike Srbije. (Report No. 10/19). https://www.paragraf.rs/propisi_download/zakon_o_osnovama_ sistema_obrazovanja_i_vaspitanja.pdf

Zlatković, B., \& Petrović, D. (2016). Interkulturalno obrazovanje budućih učitelja u Srbiji. [Intercultural education of future teachers in Serbia]. In D. Petrović \& T. Jokić (Eds.), Interkulturalno obrazovanje u Srbiji (pp. 76-87). Centar za Obrazovne Politike.

\section{Notes on Contributors}

Mila Beljanski, PhD, (1979) earned her $\mathrm{PhD}$ degree in 2013 at the Faculty of Philosophy in Novi Sad, Department of Pedagogy. She co-authored a textbook and a large number of research, papers and articles in the field of education. Her special areas of interest include: family pedagogy, social pedagogy and intercultural pedagogy. She is currently employed at the Faculty of Education in Sombor, University of Novi Sad, as an assistant professor in the field of pedagogical sciences. She is a reviewer for pedagogical and humanities journals, author and moderator of accredited seminars for teachers.

Emina Dedić Bukvić Ph.D., is Assistant professor at the Department of Pedagogy of the Faculty of Philosophy at University of Sarajevo. Her research interests are education of teachers and pedagogues, professional development of teachers and pedagogues, intercultural education and education policy in the region and further abroad. She is focused on pedagogical and didactic training in the study program of teaching faculties. In this area she was project manager at the project named "Guidelines for the advancement of the teaching profession", and also she has been member of several projects that questioned teacher's competences. 